\title{
TEKS DAN DISKURSUS OTORITAS MENURUT KHALED M. ABOU EL-FADL
}

\author{
Muhammad Fahmi Hidayatullah \\ Universitas Islam Malang \\ E-mail: m.fahmihidayatullah@unisma.ac.id
}

\section{Firmanda Taufiq}

UIN SUnan Kalijaga Yogyakarta

E-mail: firmandataufiq@gmail.com

\begin{tabular}{|c|c|c|}
\hline Received & Revised & Accepted \\
\hline 10 Januari 2021 & 10 Februari 2021 & 28 Maret 2021 \\
\hline
\end{tabular}

\section{AUTHORITY TEXTS AND DISCOURSE ACCORDING TO KHALED M. ABOU EL- FADL'S PERSPECTIVE}

\begin{abstract}
Islamic law is a construction of the two highest authorities in Islam, namely the Koran and hadith. In it contains authoritative references in religious matters. Meanwhile, in Khaled's view, Islamic jurists are a source of legitimacy in interpreting religious texts. Khaled tried to criticize the construction of authoritarianism in Islamic law, especially regarding the criticism of the misogynistic fatwas issued by the Council for Scientific Research and Legal Opinion (CRLO) and The Society for Adherence to the Sunnah (SAS). In this article, this article analyzes and examines how Khaled M. Abou El-Fadl's ideas offer in matters of text and discourse of authority in Islamic studies, especially those related to the interpretation of religious texts, namely the Al-Quran and hadith. While the method used in this research is a qualitative method using a descriptive-analysis approach. From various facts and data obtained, then analyzed and narrated descriptively with reference to the focus of this study. Based on the research findings, it was found that religious texts should be able to be translated and read properly according to their context, especially the authority and authoritarianism inherent in Islamic studies.

Keywords: text, discourse, authority, and Khaled M. Abou Fadl.

\section{Abstrak}

Hukum Islam adalah sebuah konstruksi atas dua otoritas tertinggi dalam Islam, yakni AlQuran dan hadis. Didalamnya memuat rujukan otoritatif dalam persoalan keagamaan. Sementara itu, dalam pandangan Khaled, kalangan ahli hukum Islam menjadi sumber legitimasi dalam menafsirkan teks-teks keagamaan. Khaled berusaha mengkritik konstruksi
\end{abstract}


otoritarianisme dalam hukum Islam, terutama mengenai kritik atas fatwa-fatwa misoginis yang telah dikeluarkan oleh Council for Scientific Research and Legal Opinion (CRLO) dan The Society for Adherence to the Sunnah (SAS). Didalam artikel ini berupaya menganalisis dan mengkaji bagaimana tawaran pemikiran Khaled M. Abou El-Fadl dalam persoalan teks dan diskursus otoritas dalam kajian Islam, terutama terkait dalam tafsir terhadap teks-teks keagamaan, yakni Al-Quran dan hadis. Sementara metode yang digunakan dalam penelitian ini, yakni metode kualitatif dengan menggunakan pendekatan deksriptif-analisis. Dari berbagai fakta dan data yang didapatkan, selanjutnya dianalisis dan dinarasikan secara deskriptif dengan mengacu pada fokus penelitian ini. Berdasarkan pada temuan penelitian didapatkan bahwa seharusnya teks-teks keagamaan seharusnya mampu ditafsirkan dan dibaca dengan baik sesuai dengan konteksnya, terutama otoritas dan otoritarianisme yang melekat dalam kajian keislaman.

Kata kunci: teks, diskursus, otoritas, dan Khaled M. Abou Fadl.

\section{Pendahuluan}

Hukum Islam merupakan hasil kontruksi dua otoritas tertinggi dari ajaran Islam, yaitu Al-Qur"an dan Hadis. Al-Quran merupakan representasi dari otoritas (kewenangan) Allah. ${ }^{1}$ Muslim yang tulus akan selalu merujuk pada kitab suci AlQuran ketika mereka sedang menghadapi masalah didalam kehidupannya. Nabi sebagai sosok otoritatif (berwenang penuh), utusan Allah dengan integritas kepercayaan yang dimiliki dalam menafsrikan teks dari Allah SWT. Sifat tersebut sesuai dengan sifat wajib yang dimilikinya, sehingga tanpa keraguan sedikitpun dalam menjaga amanah yang diberikan Allah.

Khaled berpendapat bahwa sumber legitimasi tekstual berasal dari ahli hukum Islam sendiri. ${ }^{2}$ Hal ini menjadikan hukum Islam dalam keadaan dilematis, dimana intelektual muslim melakukan legitimasi didasarkan terhadap kemampuan membaca, memahami, termasuk menafsirkan kehendak Tuhan. Pandangan mereka bahwa kedudukan kehendak Tuhan tersembunyi dibalik teks, maka tugas ahli hukum untuk mengkaji dan menemukannya. ${ }^{3}$

Melalui asosiasi hukum, para ahli hukum melegalitaskan kekuasaan didasarkan pada kewibawaan dengan formalitas struktur dan tingkatan sebagai . fase sejarah Islam. Berdasarkan hal tersebut menjadi penyebab sikap otoriter dan otoritarianisme muncul dalam islam. Fenomena ini merisaukan, karena hakikat hukum Islam pada dasarnya dinamis, inklusif (terbuka), elegan, dan egaliter bertransformasi menjadi kaku atau stagnan tanpa dinamika.

Dalam buku yang ditulis oleh Khaled tentang bagaimana menghadapi konstruksi otoritarianisme dalam hukum Islam yang berjudul Speaking in God's

\footnotetext{
${ }^{1}$ Raisul, "Pemikiran Hukum Islam Khaled Abou El Fadl," Mazahib: Jurnal Pemikiran Hukum Islam XIV, no. 2 (2015), https://journal.iain-samarinda.ac.id/index.php/mazahib/article/view/343/291, h. 145 .

${ }^{2}$ Asriaty, "TEKSTUALISME PEMIKIRAN HUKUM ISLAM (Sebuah Kritik)," Mazahib: Jurnal Pemikiran Hukum Islam 11, no. 1 (2013): 1-13, samarinda.ac.id/index.php/mazahib/article/view/112, h. 5.

${ }^{3}$ Mohammad Ridwan, "KONSTRUKSI OTORITARIANISME HUKUM ISLAM MENURUT KHALED M. ABOU EL-FADL," Fenomena 9, no. 1 (2017), h. 188.
} 
Name. ${ }^{4}$ Ia membahas mengenai otorisasi dalam Islam, latar belakang buku ini dibuat dari esai singkat yang ditulis Khaled yang mana tulisannya berisikan tentang hukum Islam atas kritik fatwa-fatwa misoginis yang dikeluarkan oleh Council for Scientific Research and Legal Opinion (CRLO) dan The Society for Adherence to the Sunnah (SAS). Anggapan Khaled terhadap fatwa tersebut menunjukkan kedzaliman tindakan karena merendahkan kedudukan wanita dan fatwa tersebut dalam kategori otoritarianisme pemikiran hukum Islam. ${ }^{5}$ Adapun fatwa tersebut tentang hukum wanita menggunakan bra, hukum wanita berziarah ke kubur, hukum suami meminum air susu istrinya dan hukum wanita mengemudi mobil.

Hukum Islam hakikatnya adalah seperangkat peraturan dari wahyu Allah dan Sunnah Rasul berhubungan dengan pengakuan perilaku manusia bersifat mengikat sebagai jati diri umat beragama Islam termanifestasi dalam suasana damai dan patuh baik secara vertikal ataupun horizontal. Khaled menggunakan tradisi pemikiran Islam tradisional dan epistemologi keilmuan Barat sebagai solusi secara otoritatif serta untuk dapat mengembalikan hukum Islam di zaman modern. ${ }^{6}$

Beberapa penelitian terkait pemikiran Khaled Abou Fadl, terutama mengenai otoritarian dan otoritarianisme, misalnya saja artikel yang ditulis oleh Akhmad Fakhruddin Fajrul Islam yang membahas mengenai konsep otoritas dan otoritarianisme dalam pandangan Khaled M. Abou El-Fadl. Didalam penelitian tersebut mengulas bagaimana kerangka konseptual otoritas dan otoritarianisme dalam Islam. ${ }^{7}$ Dalam pandangan Khaled, bahwa teori otoritas digunakan sebagai upaya dalam mengkonstruksi gagasan mengenai pemegang otoritas dalam diskursus keislaman. Selanjutnya, penelitian yang dilakukan oleh Mohammad Ridwan terkait konstruksi otoritarianisme dalam hukum Islam menurut Khaled M. Abou El-Fadl menelaah terkait antara relasi teks, pembaca, dan pengarang dalam persolan hukum Islam. ${ }^{8}$ Ia dianggap berhasil dalam meletakkan perbedaan antara otoritatif dan otoriter dalam pembacaan yang terkait dengan pengarang. Khaled menawarkan metodologi penafsiran yang berkaitan dengan pengarang, teks, dan konteks, serta pembaca.

Lebih lanjut, penelitian yang dilakukan oleh Moh. Muhtador dalam artikelnya diulas terkait pergulatan otoritas dan otoritarianisme dalam penafsiran dengan menggunakan perspektif pembacaan hermenneutis Khaled M. Abou El-

\footnotetext{
${ }^{4}$ Khaled Abou El-Fadl, Speaking In God's Name Islamic Law, Authority, and Women (Oxford: Oneworld, 2001).

${ }^{5}$ Iman Fadilah, "APLIKASI HERMENEUTIKA DALAM FIQH PEREMPUAN (Studi Pemikiran Khaled Abou El Fadl Tentang Fiqh Perempuan Dalam Fatwa CRLO)," Iqtisad 3, no. 1 (2016): 22-51, h. 22.

${ }^{6}$ Mahsun, "Rekonstruksi Pemikiran Hukum Islam Melalui Integrasi Metode Klasik Dengan Metode Saintifik Modern," Al AHkam 25, no. 1 (2015): 1-18, h. 1.

${ }^{7}$ Ahmad Fakhruddin Fajrul Islam, "Konsep Otoritas Dan Otoritarianisme Penafsiran Khaled M. Abou El Fadl," Tafaqquh 4, no. 1 (2016), h. 32.

${ }^{8}$ Ridwan, "KONSTRUKSI OTORITARIANISME HUKUM ISLAM MENURUT KHALED M. ABOU ELFADL.", h. 187.
} 
Fadl. ${ }^{9}$ Didalam penelitian tersebut mengangkat pemikiran Khaled dalam persoalan otoritas dalam agama dan konteks penfasiran Al-Quran. Ia berpendapat bahwa seharusnya melakukan konsep pembacaan agar terhindar dari sikap otoritarianisme dalam menafsirkan Al-Quran. Selain itu, penelitian mengenai pemikiran Khaled M. Abou Fadl juga dilakukan oleh Abdullah Hanif mengenai tinjauan dekonstruktif atas konsep otoritas. ${ }^{10}$ Penelitian ini mengkaji bagaimana fenomena otoritarianisme menjadi diskursus dalam pemikiran Islam kontemporer. Dalam pandangan Khaled, fenomena tersebut merupakan konsekuensi dari keterwakilan manusia atas otoritas Islam.

Sementara itu, didalam penelitian ini mengkaji bagaimana relativitas teks dan otoriarianisme dalam Islam menurut pandangan Khaled M. Abou El-Fadl. Dalam persoalan tersebut, Khaled menawarkan metode dan pendekatan dalam mengkaji dan meneliti teks-teks keagamaan, terutama dalam upaya menafsirkan Al-Quran dengan menggunakan pembacaan dan tafsir kontemporer. Melalui penelitian ini, maka penafsiran teks-teks keagamaan seharusnya lebih mengakomodir konteks permasalahan yang tengah dihadapi masyarakat dan tidak menafikan konteks atas tafsir keagamaan, terutama dalam kajian Islam.

\section{Metode Penelitian}

Penelitian ini merupakan penelitian kualitatif dengan menggunakan metode deskriptif-analisis. sedangkan objek penelitian yang dikaji dan diteliti yakni terkait teks dan otoriarianisme dalam perspektif kajian islam. peneliti menelusuri berbagai data dan fakta terkait topik penelitian, serta mengklasifikasikan berdasarkan tema dan fokus pembahasan dalam penelitian ini. selanjutnya, peneliti mengkaitkan beberapa data dan fakta yang ditemukan dengan diskursus teks dan otoritarianisme dalam permasalahan kajian islam kontemporer, terutama terkait tafsir atas al-quran dan hadis mengenai permasalahan di dunia modern.

\section{Hasil Penelitian dan Pembahasan \\ Konsep Otoritas dan Otoritarianisme}

Khaled M. Abou El Fadl menawarkan konsep otoritas dan otoritarianisme Islam melalui karya Atas Nama Tuhan : Dari Fikih Otoriter ke Fikih Otoritatif. Islam mengakui dan mengakomodir semua usaha manusia dalam bentuk ijtihad dalam memahami tujuan Tuhan. Bahkan pelaku ijtihad, diberikan pahala hasil ijtihad yang dilakukannya. Keberadaan imbalan inilah manusia tertarik untuk berijtihad tanpa rasa takut gagal atau salah dalam memahami maksud Tuhan. Sehingga wajar bilmana banyak mujtahid bermunculan dalam mencari kebenaran hakiki.

\footnotetext{
9 Moh. Mohtador, "Pergulatan Otoritas Dan Otoritarianisme Dalam Penafsiran (Pembacaan Hermenuetis Khaled Abou El Fadl)," Qof: Jurnal Studi Al Qur'an Dan Tafsir 2, no. 1 (2018): 65-75, h. 65.

${ }^{10}$ Abdulloh Hanif, "TINJAUAN DEKONSTRUKTIF ATAS KONSEP OTORITAS KHALED M. ABOU EL FADL," Refleksi 20, no. 1 (2020): 25-45, h. 26.

${ }^{11}$ Khaled Abou El-Fadl, Atas Nama Tuhan: Dari Fikih Otoriter Ke Fikih Otoritatif (Jakarta: Serambi Ilmu Semesta, 2004).
} 
Namun yang disayangkan adalah, praktik ijtihad sering dijumpai tokoh agama dengan pemikiran Islam ortodoks. ${ }^{12}$ Walaupun hakikatnya mengajarkan manusia tentang jalan mencapai kebenaran yang dapat ditempuh semua orang, serta keberagaman dan egaliterianisme, beberapa kelompok bersikap keras terhadap doktrin agama dengan menganggap sifat tunggal, padu, pembuktian kebenaran dengan sendiri dan sederhana. Selain itu, rasa bangga muncul atas keterbukaan gagasan dan aksesibilitas terhadap kebenaran, namun disisi lain rasa cemas juga muncul ketika digambarkan persitiwa hancurnya kewenangan khazanah intelektual Islam.

Rasa cemas inilah yang menyebabkan munculnya kesewenang-wenangan dalam hukum Islam. Sebagai poros agama, hukum Islam menghadapi trauma modernitas dan kolonialisme dan ini berdampak pada munculnya sikap otoriter dalam memperlakukan teks-teks yang bersifat otoritatif atau yang disebut dengan otoritarianisme. Merebaknya bentuk otoritarianisme seperti inilah menurut Amin Abdullah digambarkan sebagai "pengguna kekuasaan Tuhan" (author) untuk membenarkan tindakan sewenang-wenang pembaca (reader) dalam memahami dan menginterpretasikan teks. ${ }^{13}$

Menurut Khaled, pembahasan tentang otoritas tampaknya sangat penting dalam Islam, alasannya jika beragama tanpa otoritas, maka beragama dengan cara relatif atau subjektif. ${ }^{14}$ Oleh karena itu, perlu kebakuan dalam beragama (alTsawabit). Sifat otori tas secara umum yaitu meminta pihak lain untuk melakukan atau tidak seseuai dengan keinginan pihak dengan otoritas yang dimilikinya.

Dengan mengutip R.B. Friedman, Khaled membedakan antara "memangku otoritas" (being in authority) dan "memegang otoritas" (being an authority). Memangku otoritas artinya menduduki jabatan resmi yang memberinya kekuasaan untuk mengeluarkan perintah atau arahan. Pemegang otoritas disini seseorang meninggalkan pendapat pribadinya karena tunduk pada pengarang otoritas yang dipandang memiliki pengetahuan dan pemahaman yang lebih baik studi. ${ }^{15}$

Hukum Islam secara kukuh menentang kodifikasi dan penyeragaman hingga masa modern ini. Dalam penerapan metodologi hukum Islam bersifat terbuka dan anti otoritarianisme. ${ }^{16}$ Pendekatan yang digunakan pada hukum Islam meliputi pendekatan metodologis, prinsip normatif, serta hukum positif. Hukum positif dikembangkan oleh ahli hukum dan bukan dari para hakim. Secara sistematis dalam penentuan suatu hukum para ahli hukum menggabungkan dan juga memadukan keputusan hukum dari para hakim ke dalam sistem hukum normatif. Dalam hal ini banyak dari ahli hukum yang berperan sebagai hakim, tetapi tidak semua hakim berperan sebagai ahli hukum

\footnotetext{
${ }^{12}$ Raisul, "Pemikiran Hukum Islam Khaled Abou El Fadl”, h. 149

${ }^{13}$ Hujair Sanaky, "Gagasan Khaled Abou El Fadl Tentang Problem Otoritarianisme Tafsir Agama Pendekatan Hermenutik Dalam Studi Fatwa-Fatwa Keagamaan," Al Mawarid XIV, no. 1 (2005), h. 229.

${ }^{14}$ Ahmad Badi, "Kritik Otoritarianisme Hukum Islam (Kajian Pemikiran Khaled M. Abou Al Fadl,"

Tribakti: Jurnal Pemikiran KeIslaman 27, no. 1 (2016): 84-112, h. 91.

${ }^{15}$ Ulya, "Studi Kritis Terhadap Ide Khaled Abou Al- Fadl Dalam Speaking In God 's Name," Hermeneutik2 9, no. 1 (2015): 139-6o, file:///C:/Users/FAHMI/Downloads/887-3214-1-PB.pdf, h. 150.

${ }^{16}$ Fadilah, "APLIKASI HERMENEUTIKA DALAM FIQH PEREMPUAN (Studi Pemikiran Khaled Abou El Fadl Tentang Fiqh Perempuan Dalam Fatwa CRLO)", h. 48.
} 
dan dari berbagai kasus dalam pemecahan hukum sekaligus pengembangan hukum Islam itu yang berperan adalah sarjana dan akademisi hukum.

Dalam praktiknya hukum Islam hingga masa modern ini dijadikan sebagai seperangkat aturan (ahkam) yang mapan, statis dan tertutup yang diterapkan tanpa menyisakan ruang yang besar untuk pengembangan dan keragaman, dengan kata lain hukum Islam di masa sekarang dipandang sebagai seperangkat aturan bukan sebuah pemahaman (fikih). Pada abad 20 terdapat seruan untuk membuka ijtihad lagi dengan tujuan menghasilkan aturan-aturan baru, hal ini hanya akan menghasilkan ketentuan positif baru yang tidak memiliki pembenaran konseptual yang diperlukan. Dengan begitu aturan tersebut tidak membuat sebuah sistem hukum yang bisa menopang diskursus intelektual yang kreatif atau dengan kata lain ijtihad kontemporer menggantikan peraturan lama dengan atauran baru tanpa membangun metodologi untuk pengembangan selanjutnya dan tanpa adanya peluang diskursus yang bisa dikembangkan. ${ }^{17}$

Proses ijtihad baru ini sering kali diawali dengan mengutip beberapa bukti dari pengalaman pribadi atau riwayat pilihan yang dinisbatkan kepada Nabi dan dengan menyebutkan hukum Tuhan yang begini begitu. Contoh ijtihad baru yang dibuat oleh neoijtihad yakni seperti pernyataan bahwa perempuan memiliki hak untuk terlibat dalam proses politik maka ia mengutip sebuah riwayat tentang seorang perempuan yang berdebat dengan khalifah Umar ibn al-Khathab tentang pembatasan besaran mahar. ${ }^{18}$ Dimana ketika Umar menyadari bahwa argumentasi perempuan tersebut lebih kuat kemudian umar mengakui kesalahannya, dari hal ini seorang pelaku neoijtihad akan menyatakan apa pun aturan yang sedang berusaha didukungnya. Kemudian juga ketika ia (neo-ijtihad) menyatakan bahwa perempuan memiliki hak untuk mencerai suaminya tanpa ada batasan, ia mengutip riwayat tentang seorang perempuan yang mengeluh kepada Nabi kalau ia telah dipaksa ayahnya untuk menikah dengan seorang laki-laki tertentu dan kemudian Nabi memberikan hak untuk membatalkan pernikahannya. Sehingga dilihat dari otoritas persuasif dari dua hal tersebut apabila ditentang dengan bukti-bukti yang berbeda, neo-ijtihad itu dengan tidak merasa malu akan berorientasi pada hasil dan bersikap berat sebelah.

Para pendukung neo-ijtihad ini terdiri dari aktivis politik dan sosial yang hanya mengenyam sedikit pendidikan kesarjanaan Islam dan mereka ingin membangun ulang hukum Islam dengan aturan-aturan yang dogmatis dan simplistik. Mereka berpendapat bahwa hukum Islam berubah menjadi aturan tanpa justifikasi dan non metodologi dalam proses diskursus dan penetapan terbuka. Sehingga tidak heran bilamana penyebab runtuhnya metodologi hukum Islam tradisional adalah perubahan iklim, zaman, perubahan sosial dan hilangnya struktur sosial dan kelembagaan ilmuan hukum Islam klasik. ${ }^{19}$ ada aspek

\footnotetext{
${ }^{17}$ Muhammad Sofyan, "KONSEP HERMENEUTIKA OTORITATIF KHALED ABOU EL-FADL," Kalam: Jurnal Studi Agama Dan Pemikiran Islam 9, no. 2 (2015), h. 383.

${ }_{18}$ Zaidi Abdad, M, "Ijtihad Umar Ibn Al-Khattàb: Telaah Sosio-Historis Atas Pemikiran Hukum Islam," Istinbath, Jurnal Hukum Islam 13, no. 1 (2014), h. 45.

${ }^{19}$ Fathurrahman Azhari, "DINAMIKA PERUBAHAN SOSIAL DAN HUKUM ISLAM," Al Tahrir 16, no. 1 (2016), h. 210.
} 
kolonialisme dalam Islam, nasionalisasi lembaga wakaf Islam (awqaf) dan sekularisasi hukum Islam.

Studi kasus yang dibicarakan dalam hal ini berkonsentrasi pada fatwa-fatwa yang dikeluarkan oleh para ahli hukum yang mengklaim mewakili hukum Tuhan, dimana fatwa-fatwa ini dikeluarkan oleh (Council of Scientific Research and Legal Opinions (CRLO) yang merupakan sebuah lembaga resmi di Arab Saudi terkait pengkajian ilmiah dan fatwa. Dan juga lembaga resmi di Amerika yakni The Society for Adherence to the Sunnah (SAS).$^{20}$ Fatwa tersebut dijadikan sebagai dasar argumentasi hukum Negara yang bersifat resmi. Fatwa-fatwa yang dikeluarkan tersebut berupa permasalahan terkait dengan perempuan, yang didominasi oleh para ahli hukum yang menganut mazhab pemikiran hukum wahabi. Ciri khas pendekatan hukum Islam kontemporer yang dilakukan oleh Wahabi hasilnya bersifat pasti, kesimpulannya tidak bisa digugat, dan penetapannya bersifat kaku atau keras. $^{21}$ Sehingga kecanggihan dan kekayaan khazanah hukum Islam klasik sebagian besar tidak lagi ditemukan pada masa modernini.

\section{Teks dan Konsep Otoritarianisme}

Menurut Khaled, otoritarianisme muncul disebabkan kesalahan metodologi dalam memahami teks-teks hukum yang ada dalam al-Qur"an dan hadis oleh tiga unsur pengarang, teks dan pembaca. Seorang pembaca yang mengunci teks dalam sebuah makna tertentu dan kemudian menyajikan penetapan tersebut sebagai suatu yang given, pasti, absolut, dan menentukan. maka dia telah merusak integritas pengarang dan teks itu sendiri. ${ }^{22}$ Amin Abdullah dalam pengantar buku Atas Nama Tuhan menuliskan bahwa otoritarianisme adalah tindakan seseorang, kelompok atau lembaga yang yang "menutup rapat" atau membatasi keinginan Tuhan atau keinginan teradalam maksud teks dalam suatu batasan ketentuan tertentu, dan kemudian menyajikan ketentuan tersebut sebagai sesuatu hal yang tidak dapat dihindari, final dan merupakan hasil akhir yang tidak dapat dibantah. Jadi dalam dimensi penafsiran otoritarianisme, problem yang paling dominan dan menentukan adalah pada tingkat pembaca.

Khaled menuliskan, "if the reader chooses a particular reading of the text and claims that no other readings are possible, the text is diluted in the character of the reader. If the reader overcomes and usurps the text, the danger is that the reader stands suspended, untouchable, transcendent, and authoritarian". ${ }^{23}$

Dari teks diatas dapat ditarik kesimpulan bahwa jika pembaca sudah melampaui dan menyelewengkan teks, bahaya yang akan dihadapi adalah pembaca akan menjadi tidak efektif, tidak tersentuh, melangit dan otoriter. Otoritarianisme juga ditandai dengan penyautan pembaca dengan teks, sehingga penetapan

\footnotetext{
${ }^{20}$ Muhammad Lutfi Hakim, "Hermeneutik-Negosiasi Dalam Studi Fatwa-Fatwa Keagamaan Analisis Kritik Terhadap Penikiran Khaled M. Aboud El-Fadl.,” Istinbath, Jurnal Hukum Dan Ekonomi Islam 19, no. 1 (2020).

${ }^{21}$ Sanaky, "Gagasan Khaled Abou El Fadl Tentang Problem Otoritarianisme Tafsir Agama Pendekatan Hermenutik Dalam Studi Fatwa-Fatwa Keagamaan", h.24o.

${ }^{22}$ Nasrullah, "HERMENEUTIKA OTORITATIF KHALED M. ABOU EL FADL: METODE KRITIK ATAS PENAFSIRAN OTORITARIANISME DALAM PEMIKIRAN ISLAM,” Hunafa 5, no. 2 (20o8), h. 138.

${ }^{23}$ El-Fadl, Speaking In God's Name Islamic Law, Authority, and Women, h. 376.
} 
pembaca itu akan menjadi perwujudan teks eksklusif. ${ }^{24}$ Dampak teks dan kontruksi pembaca akan menjadi satu dan serupa. Dengan demikian, melalui proses tersebut, teks akan tunduk kepada pembaca dan secara efektif pembaca menjadi pengganti teks.

\section{Hukum Islam yang Terus Berubah}

Setiap kali seorang pembaca memiliki keyakinan bahwa ia telah menemukan makna sebenarnya dari sebuah teks atau telah menentukan kehedak Tuhan, ia akan menghadapi resiko melampaui otoritasnya dan terjerumus ke dalam sikap otoriter.

Bagaimana pembaca mendefiniskan kata "kebenaran" dari apa yang mereka baca, persoalan yang sering dihadapi oleh ahli hukum adalah, bagaimana mungkin ada beberapa jawaban atas satu pertanyaan yang benar-benar sama. Pada tataran yang mendasar, pertanyaan tersebut memunculkan persoalan tentang tujuan dan motivasi dibalik bukti-bukti tekstual. Kebenaran dan ketepatan hukum, pada kebanyakan kasus, bergantung pada keyakinan dan pembuktian dan pada kenyataaan. Sifat dari semua tindakan hukum sering kali bergantung pada pengakuan.

Contohnya, sesorang yang membeli budak perempuan dan menikahinya, tapi kemudian diketahui bahwa perempuan tersebut adalah saudara, keduanya tidak boleh melanjutkan hubungan pernikahan mereka, meskipun sebelumnya, keduanya sudah terlanjut menikah. ${ }^{25}$ Dari kasus ini, diperoleh simpulan bahwa hubungan pernikahan itu diperbolehkan atau tidak tergantung dari pengetahuan kedua belah pihak.

Namun, bagaimana jika dua orang.masing-masing memiiki keyakinan yang sama-sama kuat, Al-Juwayni dan para ahli hukum mushawwibah menyatakan bahwa dalam situasi semacam ini hukum Tuhan untuk masing-masing orang tetap menurut keyakinan kuat mereka sendiri, Namun, dalam kaitannya dengan orang lain, hukum Tuhan tetap ditangguhkan hingga keputusan hakim yang bersifat formal antara berbagai kepentingan yang saling bertentangan itu.

Setiap agama memiliki nilai atau fondasi yang sangat mendasar, yang bisa digambarkan dengan istilah ushul atau kebenaran yang pasti. Kebanyakan ahli hukum menyatakan bahwa ketidakpastian atau penetapan ijtihad dalam persoalan ushul dipandang sebagai sebentuk dosa karena dalam kategori persoalan semacam itu kebawajiban untuk mengetahui kebenaran bersifat mutlak. ${ }^{26}$ Hal-hal yang bersifat pokok dalam agama adalah persoalan yang bersifat aqliyyat (hal-hal yang kebenarannya bisa dibuktikan secara nyata dengan petunjuk akal).

Contoh hal-hal yang mendasar dalam agama adalah, kedudukan Muhammad sebagai nabi terakhir untuk umat manusia, kekekalan dan kesakralan Al-Qur"an,

\footnotetext{
${ }^{24}$ Sanaky, "Gagasan Khaled Abou El Fadl Tentang Problem Otoritarianisme Tafsir Agama Pendekatan Hermenutik Dalam Studi Fatwa-Fatwa Keagamaan", h. 250.

${ }^{25}$ Fauziatu Shufiyah, "Pernikahan Dini Menurut Hadis Dan Dampaknya," Living Hadis 3, no. 1 (2018), h. 52-53.

${ }^{26}$ Abd Wafi Has, "Ijtihad Sebagai Alat Pemecahan Masalah Umat Islam," Epistemez 8, no. 1 (2013), h. 107.
} 
posisi sunah sebagai sumber penetapan hukum. ${ }^{27}$ Semuanya ini dijelaskan dalam bentuk teks-teks Islam, sehingga ada interpretasi atau pengajian ulang terhadap teks-teks tersebut.

Khaled disini juga mengangkat sebuah kasus sebagai contoh sebuah lembaga hukum secara konsisten menyatakan bahwa perempuan muslim harus menutup seluruh tubuh dan rambutnya. Ketika ada bantahan terhadap peraturan ini, disini pihak yang membantah harus berupaya memberikan bukti atau argumen untuk mendukung bantahan atau sanggahan tadi. Melalui bukti dan argumen yang dikemukakan tadi apakah mungkin bahwa lembaga itu mengkaji ulang kembali apa yang sudah menjadi keputusan mereka?. Jawabannya tergantung pada bukti yang diberikan dan seberapa kuat argument yang dilontarkan.

Dalam hal ini, Khaled memberikan contoh kasus perempuan dan ayahnya yang berbeda mahzab dan menikah dengan laki-laki yang bukan pilihan ayahnya, sementara ayahnya menikahkan perempuan tersebut dengan laki-laki yang bukan pilihannya. Kedua orang ini yakin dengan mahzabnya masing-masing, sehingga dalam perkara ini, hukum Tuhan bisa ditangguhkan hingga seorang hakim memutuskan perkara mereka. Jika, hukum yang digunakan adalah hukum yang ada di wilayah tersebut bahwa ayah berada pada posisi yang benar, maka perempuan terposisi sebagai pihak yang keberatan dan menolak keputusan hakim atas hukum keyakinan moral yang dianutnya.

Di sisi hakim, mungkin perempuan yang menentang keputusan ini dianggap sebagai seorang pembangkang, namun perempuan ini tidak bisa dijatuhi hukuman karena dia (perempuan) dipandang sebagai seorang muta'awwilah (pembangkang dengan sebab yang mendasar). Dengan demikian, menurut Khaled, keyakinan yang dimiliki perempuan adalah keyakinan yang benar-benar berbasis iman, secara moral dan agama wajib untuk tidak mematuhi keputusan hakim. Penolakan yang dialakukan tidak bisa dipandang sebagai seorang yang otirter akan tetapi bisa disebut sebagai pemegang teguh prinsip yang diyakininya. Dalam hal ini, dapat disimpulkan bahwa, kita bisa saja melakukan apa yang menurut kita yakini, dengan disertai argumen-argumen yang sahih dan benar.

Untuk membendung, mencegah dan menghindari diri, kelompok, dan organisasi keagamaan dari sikap otoritarianisme, Khaled dalam mengajukan lima prasyarat, ${ }^{28}$ yaitu:

a. Kejujuran (honesty) merupakan sikap terbuka tanpa sandiwara terhadap sesuatu yang tidak diketahui dan terang terangan terhadap ilmu dan kemampuan yang dimiliki dalam memahami kehendak Tuhan.

b. Kesungguhan (diligence), merupakan kerja keras dengan etos kerja tinggi dan senantiasa waspada terhadap hak miliki orang lain dengan menghindarkan diri dari segala sesuatu yang merugikan orang lain. Mengingat semakin besar kesalahan dilakakukan terhadap orang lain, maka pertanggungjawabannya juga

\footnotetext{
${ }^{27}$ Alamsyah, "Dinamika Otoritas Sunnah Nabi Sebagai Sumber Hukum Islam," Al 'Adalah XII, no. 3 (2015, h. 483 .

${ }^{28}$ Iman Nurhakim, "Pertautan Antara Reader, Text, Dan Author Dalam Memahami Nash (STudi Hermeneutika Khaled M. Aboe El Fadl Dan Buku Speaking in God's Name: Islamic Law, Authority, and Woman)," Maghza 2, no. 2 (2017), h.12.
} 
semakin besar disisi Tuhan.

c. Keseluruhan (comprehensiveness), merupakan usaha total untuk menyelidiki kehendak Tuhan disertai pertimbangan seluruh nashah yang relevan.

d. Rasional (reasonableness), yaitu usaha menafsirkan dan menganalisis hasil nashsh dengan logis dan dapat diterima oleh akal pikiran sehat.

e. Pengendalian diri (self-restraint), yaitu usaha melakukan kontrol diri dengan sadar tanpa sewenang-wenang dengan memperhatikan aspek kesesuaian dalam menafsirkan kehendak Tuhan.

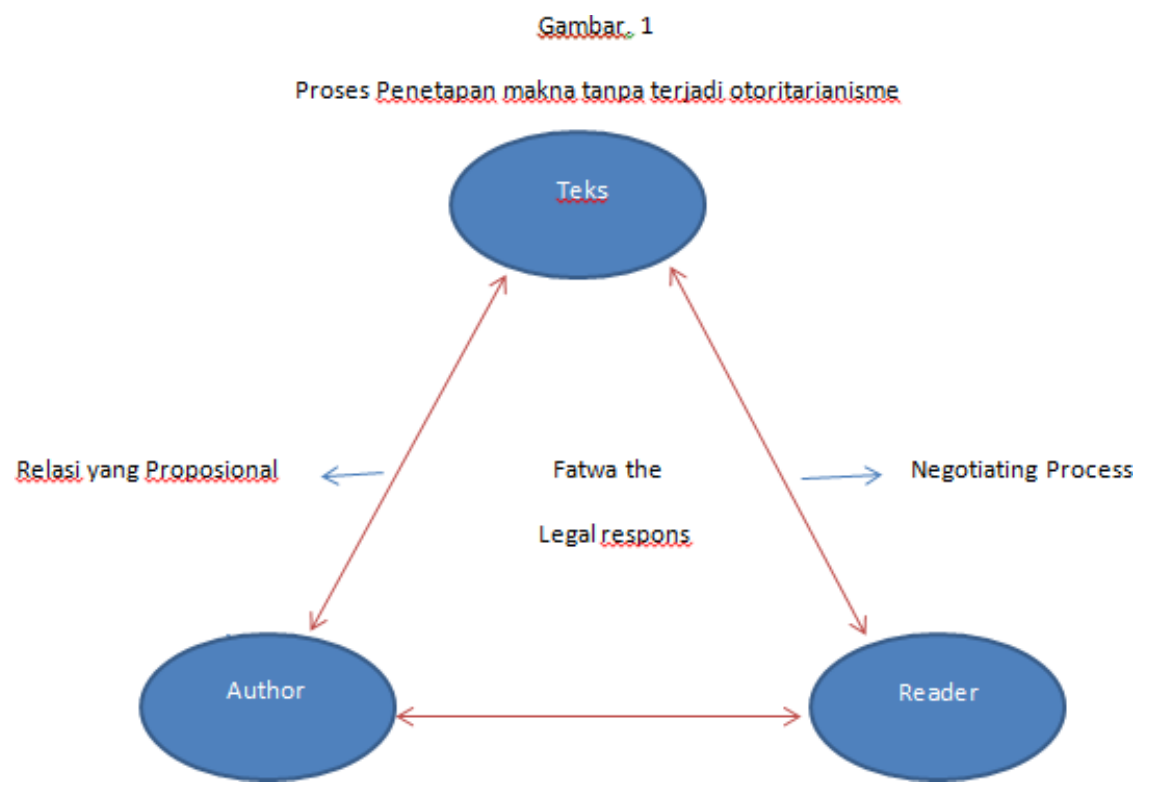

\section{Fatwa Otoritarian Wanita}

Dalam hal ini akan dibahas terkait dengan fatwa-fatwa permasalahan perempuan yaitu kasus tentang bra, sepatu bertumit tinggi, dan perjanjian pernikahan.

a. Kasus Bra

Ada seseorang yang menanyakan kepada Syekh ibn Jibrin apakah mengenakan bra diperbolehkan menurut hukum Islam? Kemudian beliau menjawab dengan terus terang bahwa beberapa perempuan mengenakan pakaian tambahan untuk menciptakan kesan bahwa mereka masih muda atau perawan (jika bra mengangkat buah dada) dan jika memang demikian motifnya maka hal tersebut dipandang sebagai penipuan yang dilarang. Tetapi jika perempuan mengenakan bra untuk kesehatan dan pengobatan maka hal tersebut diperbolehkan. Berdasarkan argumentasi Ibn Jirin tersebut beliau mengambil sebuah hadis yang dinisbatkan kepada Nabi yang berbunyi "siapapun yang berlaku curang bukanlah kelompok kamu”. Namun konteks riwayat tersebut tidak berkaitan dengan bra. Akan tetapi hadis tersebut diriwayatkan bahwa Nabi menemukan seorang pedagang yang berlaku curang saat menjajakan dagangannya lalu Nabi menyatakan bahwa bentuk pengelabuah dalam menjajakan dagangan dipandang sebagai perilaku yang tidak bisa diterima. Ibn Jirin tidak 
mengungkapkan apakah ia menggunaan asumsi berbasis nilai atau iman bahwa perempuan mirip dengan barang dagangan.

b. Sepatu Bertumit Tinggi

Dalam memahami persoalan fatwa tentang boleh tidaknya perempuan mengenakan sepatu bertumit tinggi. Fatwa ini dikeluarkan oleh sekelompok ahli dalam lembaga CRLO dan Syaikh ibn Baz, Syaikh ibn Jibrin, dan Syaikh alUtsaimin. Mereka ini berpendapat bahwa sepatu bertumit tinggi tidak diperbolehkan dalam Islam. Adapun sebab dari dilarangnya hal tersebut yakni sepatu semacam itu tidak menyehatkan dan berbahaya bagi perempuan karena bisa menyebabkan seorang perempuan terkilir dan jatuh. Selain itu sepatu itu juga dianggap menipu karena menjadikan perempuan terlihat lebih tinggi dan dapat menimbulkan fitnah, sebab akan menonjolkan paha perempuan. Kemudian untuk kesekian kalinya metodologi hukum atau bukti tekstual yang digunakan dalam membuat penetapan tersebut tidak disebutkan. Sehingga memunculkan persoalan tentang kapasitas para wakil khusus yang ada di CRLO tersebut dan memunculkan pertanyaan apakah penetapan hukum ini diserahkan pada kapasitas masingmasing individu semata dan murni dipandang sebagai pendapat individu maka fakta nya harus dikemukakan.

\section{c. Perjanjian pernikahan}

Pernikahan yang perbincangkan disini yaitu terkait dengan legalitas pernikahan misyar yang popular di Arab Saudi. Pada pernikahan ini seorang lakilaki menikahi seorang perempuan dengan niat akan menceraikannya setelah beberapa lama namun tanpa memberitahuka niat nya itu kepada calon isterinya. Kejadiannya seperti ini, saat itu seorang laki-laki pergi belajar ke luar negeri dan selama berada di luar negeri ia akan menikahi seorang perempuan dengan tidak mengungkapkan niatnya untuk menceraikannya apabila pendidikannya telah selesai. CRLO dan Ibn Baz menetapkan bahwa pernikahan tersebut dipandang sah dan sama sekali tidak mengecam pihak laki-laki atas perilakunya yang curang. CRLO dan Ibn Baz menyatakan dua hal atas terbentuknya hukum ini.

Pertama, kebanyakan ahli hukum klasik sepakat bahwa bentuk pernikahan seperti itu di pandang sah. Kedua pernikahan tersebut berbeda dengan nikah kontrak. Sehingga dapat diambil kesimpulan bahwa sulit untuk mengetahui peran teks atau pengarang dalam penetapan fatwa-fatwa ini. Ketika kita menganalisis dalam perspektif perbandingan menampilkan bukti-bukti yang ada terkait dengan penetapan fatwa maka satu-satunya yang terlihat adalah suara penafsir yang telah mengontrol proses penetapan itu.

Dalam pemilihan bukti berkaitan dengan peran seorang wakil khusus CRLO dimana bersikap selektif ketika menggunakan bukti, namun jika tidak maka dapat dipandang sebagai pelanggaran dalam bersikap jujur, bersungguh- ungguh dan menyeluruh dalam menganalisis bukti. Sikap selektif disini yaitu memeriksa buktibukti yang ada sehingga ia tidak berusaha menemukan perintah Tuhan tetapi mencari dukungan dari perintah Tuhan maka itu dipandang sebagai pelanggaran yang nyata terhadap kewajiban untuk bersungguh-sungguh dan menyeluruh dalam menganalisis bukti. 
Selain penelusuran bukti yang selektif juga perlu mengemukakan tentang pengungkapan yang bersikap selektif. Diasumsikan bahwa seorang wakil khusus telah bersungguh-sungguh serta menyeluruh dalam menganalisis perintah Tuhannya dilihat dari sejauh mana ia harus mengungkapkan seluruh pembuktian kepada wakil umum? Jawaban dari pertanyaan ini bergantung pada keberwenangan yang diklaim oleh wakil khusus. Kewajiban yang harus dilakukan oleh wakil khusus yaitu bersungguh-sungguh, jujur, dan menyeluruh dalam menganalisis bukti dengan interpretasi dari berbagai komunitas yang memformulasikan hukum Islam dan dengan jujur menggambarkan kesimpulan yang dicapai komunitas tersebut.

\section{Menyeimbangkan Berbagai Kepentingan dan Penggunaan Penalaran}

Dalam analisis hukum itu bertumpu pada penalaran dengan menarik ketentuan atau prinsip yang bersifat umum dalam serangkaian fakta. Sehingga memunculkan pertanyaan dalam menetapkan hukum, apakah sebuah situasi faktual tertentu diatur oleh suatu ketentuan-ketentuan atau metodologi yang merupakan persoalan dalam pembuatan keputusan, namun juga tetap melibatkan penalaran. Misalkan, menetapkan ketentuan tentang kesopanan dan menetapkan kententuan bahwa situasi yang dapat mendorong timbulnya seksual harus dihindari. Pernyataan ini menimbukan pertanyaan-pertanyaan yakni situasi seperti apa yang dapat dipandang sebagai pelanggaran terhadap aturan kesopanan yang melibatkan sejumlah besar penalaran? Bagaimana dan standar apa yang mereka gunakan dalam menentukan bahwa suatu situasi itu bertentangan dengan aturan kesopanan?

Berdasarkan pertanyaan-pertanyaan tersebut tidak ada jawaban yang diberikan oleh ahli hukum. Sehingga bisa simpulkan bahwa seorang hakim memiliki kewenangan untuk membuat penetapan hukum bukan karena ia orang yang paling memenuhi syarat untuk memahami suatu kenyataan tetapi karena posisi kelembagaan mereka, yang membuat mereka dapat memberikan keputusan hukum. Artinya, hakim tersebut memperoleh kompetensinya dalam kelembagaan itu sejauh dengan berbagai fakta yang ada bukan karena ia mempunyai pemahaman yang lebih dari pada seorang ilmuwan atau pemerhati sosial.

Fatwa persoalan terkait dengan pelarangan perempuan mengemudikan mobil dimana fatwa ini dikeluarkan oleh Ibn Baz dan Ibn Fawzan dan dijadikan sebagai hukum negara Arab Saudi. ${ }^{29}$ Dikatakan bahwa Tuhan tidak melarang perempuan naik mobil tetapi melarangnya mengemudikan mobil. Larangan itu juga berlaku untuk perempuan yang membawa suaminya yang buta atau ayahnya yang sudah lanjut usia pergi berkendaraan. Bahkan sekalipun jika seorang perempuan terpaksa mengemudikan mobil dengan kondisi darurat Ibn Fawzan tetap melarangnya. Padahal banyak perempuan yang menunggang undan dan kuda pada masa Nabi dan setelahnya namun fakta historis dan tekstual tentang persoalan ini tidak dihiraukan.

\footnotetext{
29 Reza Bakhtiar Ramadhan, "Keputusan Hukum Izin Mengemudi Bagi Perempuan Saudi Arabia Ditinjau Dalam Perspektif Maqashid As-Syari ’ Ah,” Islamic World and Politics 3, no. 1 (2019), h. 469.
} 
Dalam pelarangan ini Ibn Baz berargumen tentang bahayanya perempuan mengemudikan mobil yang akan memicu ikhtilath (berkumpulnya laki-laki dan perempuan dalam satu tempat), dan khalwah (berkumpulnya laki-laki dan perempuan yang bukan mahramnya dalam satu tempat) dengan argumen ini. Ia menyatakan bahwa perempuan lebih baik dirumah saja dan tidak ikut urusan publik. Intinya merunut Ibn Baz bahwa kemandirian dan mobilitas dalam bekendaraan akan menimbulkan kerugian bagi kehidupan moral dan sosial perempuan. Kemudian Ibn Fawzan menambahkan bahwa mobil yang dikendarainya bisa saja mengalami kerusakan dan kecelakaan sehingga mengancam keselamatan perempuan.

\section{Simpulan}

Dalam diskursus teks dan otoritas dalam kajian keislaman, terutama teks-teks Al-Quran dan hadis bagi Abou el-Fadl diperlukan melakukan mainstream otoritas. Rasionalisasinya adalah menghindarkan manusia beragama secara individual, subjektif, dan relatif. Hal inilah yang mengakibatkan beragama dalam sudut pandang masing-masing idnividu dengan mengabaikan teks. Disisi lain, menyandingkan otoritas dengan penetapan makna bukan berarti tanpa masalah. Permasalahan muncul jika terdapat sikap sekehendak hati dalam menafsirkan teks yang mengakibatkan munculnya sikap otoritarianisme. Sikap inilah secara tidak langsung sedang mengunci atau menutup kehendak Tuhan atau teks dalam penetapan makna. Sehingga teks yang sejatinya bersifat absolut, pasti dan dipastikan kebenarannya menjadi bias. Abou El-Fadl menentang keras sikap otoritarianisme dengan melakukan perlawanan paksa usaha menaklukkan dan menutu teks atau cara pandang terhadap teks dengan bebas, terbuka, maupun otonom dalam memahami kehendak Tuhan. Jika menjadikan teks tetap bebas, terbuka, dan otonom sebagai kehendak Tuhan, Abou El-Fadl memberikan solusi dengan memberikan media untuk mengantarkan pada pemahaman kehendak Tuhan yakni hermeneutik. Banyak orang mengenalnya dengan tafsir hermenutik sebagai gagasan Abou El-Fadl walaupun banyak yang mempermasalahkan. Tetapi media ini menjadi solusi dalam menyelesaikan otoritas dan otoritarianisme terhadap teks.

\section{DAFTAR PUSTAKA}

Abdad, M, Zaidi. "Ijtihad Umar Ibn Al-Khattàb: Telaah Sosio-Historis Atas Pemikiran Hukum Islam." Istinbath, Jurnal Hukum Islam 13, no. 1 (2014): 37-50.

Alamsyah. "Dinamika Otoritas Sunnah Nabi Sebagai Sumber Hukum Islam." Al 'Adalah XII, no. 3 (2015): 479-92.

Asriaty. "TEKSTUALISME PEMIKIRAN HUKUM ISLAM (Sebuah Kritik)." Mazahib: Jurnal Pemikiran Hukum Islam 11, no. 1 (2013): 1-13. https://journal.iainsamarinda.ac.id/index.php/mazahib/article/view/112.

Azhari, Fathurrahman. "DINAMIKA PERUBAHAN SOSIAL DAN HUKUM ISLAM." $A l$ Tahrir 16, no. 1 (2016).

Badi, Ahmad. "Kritik Otoritarianisme Hukum Islam (Kajian Pemikiran Khaled M. Abou Al Fadl.” Tribakti: Jurnal Pemikiran KeIslaman 27, no. 1 (2016): 84-112.

El-Fadl, Khaled Abou. Atas Nama Tuhan: Dari Fikih Otoriter Ke Fikih Otoritatif. Jakarta: 
Serambi Ilmu Semesta, 2004.

. Speaking In God's Name Islamic Law, Authority, and Women. Oxford: Oneworld, 2001.

Fadilah, Iman. "APLIKASI HERMENEUTIKA DALAM FIQH PEREMPUAN (Studi Pemikiran Khaled Abou El Fadl Tentang Fiqh Perempuan Dalam Fatwa CRLO)." Iqtisad 3, no. 1 (2016): 22-51.

Hakim, Muhammad Lutfi. "Hermeneutik-Negosiasi Dalam Studi Fatwa-Fatwa Keagamaan Analisis Kritik Terhadap Penikiran Khaled M. Aboud El-Fadl." Istinbath, Jurnal Hukum Dan Ekonomi Islam 19, no. 1 (2020).

Hanif, Abdulloh. "TINJAUAN DEKONSTRUKTIF ATAS KONSEP OTORITAS KHALED M. ABOU EL FADL." Refleksi 20, no. 1 (2020): 25-45.

Has, Abd Wafi. "Ijtihad Sebagai Alat Pemecahan Masalah Umat Islam." Episteme2 8, no. 1 (2013).

Islam, Ahmad Fakhruddin Fajrul. "Konsep Otoritas Dan Otoritarianisme Penafsiran Khaled M. Abou El Fadl." Tafaqquh 4, no. 1 (2016).

Mahsun. "Rekonstruksi Pemikiran Hukum Islam Melalui Integrasi Metode Klasik Dengan Metode Saintifik Modern." Al AHkam 25, no. 1 (2015): 1-18.

Mohtador, Moh. "Pergulatan Otoritas Dan Otoritarianisme Dalam Penafsiran (Pembacaan Hermenuetis Khaled Abou El Fadl)." Qof: Jurnal Studi Al Qur'an Dan Tafsir 2, no. 1 (2018): 65-75.

Nasrullah. "HERMENEUTIKA OTORITATIF KHALED M. ABOU EL FADL: METODE KRITIK ATAS PENAFSIRAN OTORITARIANISME DALAM PEMIKIRAN ISLAM." Hunafa 5, no. 2 (2008).

Nurhakim, Iman. "Pertautan Antara Reader, Text, Dan Author Dalam Memahami Nash (STudi Hermeneutika Khaled M. Aboe El Fadl Dan Buku Speaking in God's Name: Islamic Law, Authority, and Woman)." Maghza 2, no. 2 (2017).

Raisul. "Pemikiran Hukum Islam Khaled Abou El Fadl." Mazahib: Jurnal Pemikiran Hukum Islam XIV, no. 2 (2015). https://journal.iainsamarinda.ac.id/index.php/mazahib/article/view/343/291.

Ramadhan, Reza Bakhtiar. "Keputusan Hukum Izin Mengemudi Bagi Perempuan Saudi Arabia Ditinjau Dalam Perspektif Maqashid As-Syari ' Ah.” Islamic World and Politics 3, no. 1 (2019).

Ridwan, Mohammad. "KONSTRUKSI OTORITARIANISME HUKUM ISLAM MENURUT KHALED M. ABOU EL-FADL.” Fenomena 9, no. 1 (2017): 187-96. https://journal.iain-samarinda.ac.id/index.php/fenomena/article/view/1296/695.

Sanaky, Hujair. "Gagasan Khaled Abou El Fadl Tentang Problem Otoritarianisme Tafsir Agama Pendekatan Hermenutik Dalam Studi Fatwa-Fatwa Keagamaan." Al Mawarid XIV, no. 1 (2005).

Shufiyah, Fauziatu. "Pernikahan Dini Menurut Hadis Dan Dampaknya." Living Hadis 3, no. 1 (2018).

Sofyan, Muhammad. "KONSEP HERMENEUTIKA OTORITATIF KHALED ABOU ELFADL.” Kalam: Jurnal Studi Agama Dan Pemikiran Islam 9, no. 2 (2015): 373-92.

Ulya. "Studi Kritis Terhadap Ide Khaled Abou Al- Fadl Dalam Speaking In God ' s Name." Hermeneutik2 9, no. 1 (2015): 139-60. file:///C:/Users/FAHMI/Downloads/887-32141-PB.pdf. 